\title{
Effect of mental toughness on sporting performance: Review of studies
}

\author{
Authors' Contribution: \\ A Study Design \\ B Data Collection \\ C Statistical Analysis \\ D Data Interpretation \\ E Manuscript Preparation \\ F Literature Search \\ G Funds Collection
}

\author{
Monika Guszkowska AE, Katarzyna Wójcik ABEF \\ Józef Piłsudski University of Physical Education in Warsaw, Poland
}

\section{abstract}

The aim of the present review was to establish the correlation between mental toughness and sporting performance based on the results of studies published in scientific journals between 2000 and 2020 .

The keywords mental toughness and performance/ outcomes/ results/ competition were used to identify the papers. The search included the EBSCO and PubMed databases. Eventually, the analysis covered 18 articles.

The research results presented in 16 papers confirmed the positive correlations of mental toughness with sport results and performance level. No such relationship was found only in equestrian and Alpine skiing athletes. Although mental toughness in basketball players did not correlate with the sport results, it was an important predictor. Higher mental toughness was found in athletes with better sports results, and it was a positive correlate or predictor of sports results. The relationships between mental toughness and competitive experience or age were not statistically significant. Various research tools were used to measure mental toughness: PPI, PPI-A, SMTQ, MTQ48, MTI, SMTI, MeBTough.

The results confirm the positive correlation between mental toughness and sport results or performance levels in different sports, regardless of gender, age or level of sports skills. It seems appropriate to continue research on mental toughness in sport, including the relationship between mental toughness and sporting performance, differences between men and women, players in individual and team sports, the relationship between mental toughness and training experience, the athletes' age, and the effectiveness of mental toughness programs.

Keywords: mental toughness, sports result, sports performance.

\section{article details}

Article statistics: Word count: 4,504; Tables: 1; Figures: 1; References: 47

Received: February 2020; Accepted: August 2020; Published: December 2021

Full-text PDF: http://www.balticsportscience.com

Copyright @ Gdansk University of Physical Education and Sport, Poland

Indexation: Celdes, Clarivate Analytics Emerging Sources Citation Index (ESCI), CNKI Scholar (China National Knowledge Infrastructure), CNPIEC, DOAJ, EBSCO - Central \& Eastern European Academic Source, EBSCO - SPORTDiscus, EBSCO Discovery Service, Google Scholar, Index Copernicus, J-Gate, Naviga (Softweco, Primo Central (ExLibris), ProQuest - Family Health, ProQuest - Health \& Medical Complete, ProQuest - Illustrata: Health Sciences, ProQuest Nursing \& Allied Health Source, Summon (Serials Solutions/ProQuest, TDOne (TDNet), Ulrich's Periodicals Directory/ ulrichsweb, WorldCat (OCLC)

Funding: This research received no specific grant from any funding agency in the public, commercial, or not-for-profit sectors.

Conflict of interests: Corresponding author:

Open Access License: Authors have declared that no competing interest exists.

Katarzyna Wójcik, Jozef Pilsudski Academy of Physical Education in Warsaw, Marymoncka 34, Warszawa 00-968, Poland; e-mail:wojcik.catarina@gmail.com

This is an open access article distributed under the terms of the Creative Commons Attribution-Non-Commercial-NoDerivatives 4.0 International (https://creativecommons.org/licenses/by-nc-nd/4.0/), which permits use, distribution, and reproduction in any medium, provided the original work is properly cited, the use is non-commercial and is otherwise in compliance with the license. 


\section{INTRODUCTION}

Psychological preparation of athletes is one of the basic elements in sports training. In order for a player to be able to improve his/her sports skill level, he or she should effectively cope with stress, challenges and difficulties they face during the sporting competition and during training. Research indicates that participation in sports competitions is a source of strong stress [1]. It is considered that mental toughness is one of the factors determining the effectiveness of emotional self-regulation, ability to focus on performing tasks and selfconfidence [2]. Hardy, Bell and Beatti [3] argue that mental toughness means the ability to achieve goals in the face of pressure and the effect of various stressors. Therefore, it is worth paying attention to mental toughness in the context of mental preparation of an athlete.

So far, psychologists have not adopted one definition of mental toughness, and researchers propose different theoretical models of this construct [4]. Mental toughness is often presented as a set of psychological skills [5] that determine the effective coping with difficulties, such as concentration, determination, self-confidence and a sense of control [6]. According to Gucciardi, Gordon and Dimmock [7], mental toughness is linked to sports awareness, challenge and desire to succeed. This concept is also defined as the ability to recover from failure [8] or taking up challenges and pursuing a goal despite difficulties [4]. According to some researchers, mental toughness contains a cognitive, behavioural and emotional component $[9,10]$.

Different models of mental toughness have been discussed in the literature. Sheard [9], who is the author of the $3 \mathrm{C}$ model, approached mental toughness as a relatively constant property consisting of 3 factors: control, constancy and confidence. Clough et al. [8] presented the standpoint that mental toughness should be defined as a personality trait that determines responses to a challenge or pressure regardless of the situation. His $4 \mathrm{C}$ model shows mental toughness as a system of 4 factors: control, confidence, challenge and commitment.

Mental toughness is dependent on genetic factors, but is also affected by environmental influences, so it can be deliberately developed According to Crust and Clough [10], in developing mental toughness, an environment that supports, but also challenges, social support and learning through experience ending with one's own reflection is important.

In difficult situations, mentally tough people use more coping strategies, such as internal dialogue, visualization and attention control [11]. They have psychological skills that allow them to deal effectively with anxiety and set goals [12]. These skills can be developed in mental training. For example, mindfulness training is an effective tool for building mental toughness. The results of Ajilchla et al. [13] confirm the increase in mental toughness of basketball players after a 6-week mindfulness training. It is also possible to influence athletes through trainers and parents, using social support mechanisms [14].

Based on the results of qualitative research of master class athletes, trainers and psychologists, Connoughton [14] recommends the development of special educational programs for trainers and players to increase mental toughness by:

- developing self-confidence based on successes in training and sports competitions,

- setting challenging goals,

- developing good communication between an athlete and the trainer,

- building social support through relationships with other players, trainers and staff members as well as family, friends and partners.

It is widely believed in sports community that a mentally tough athlete is more likely to achieve sporting success $[9,15]$. Is this expectation confirmed by the results of scientific research? In order to answer the question whether mental toughness is linked to the level of performance in sport, articles on the relationships between mental toughness and sports results published in scientific journals between 2000 and 2020 were reviewed. 


\section{MATERIAL AND METHODS}

The scientific databases of EBSCO and PubMed were searched with the use of the following keywords: mental toughness, performance, outcomes, results, competition, sport within a specified time frame (articles published in 2000-2020). In total, 619 records were retrieved (Fig. 1).

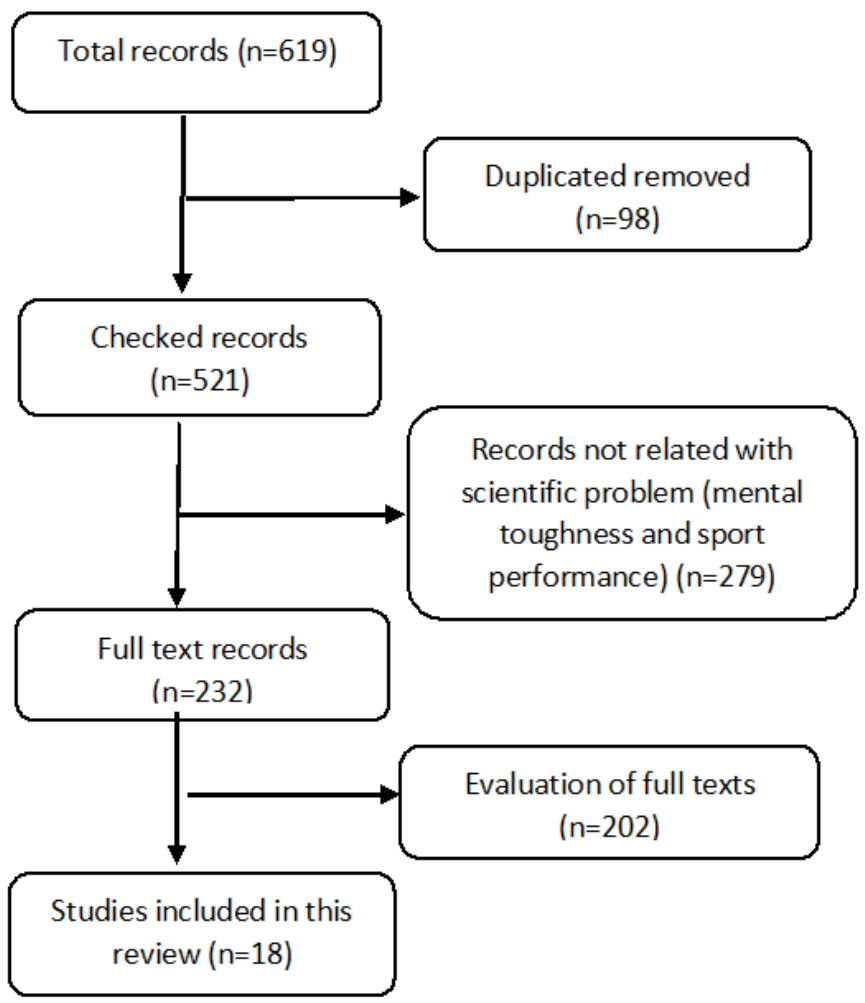

Fig. 1. Article identification process

This number was reduced to 521 after deleting duplicates of individual items. The abstracts that were unrelated to the research question were also rejected, which further reduced the number of records to 232. Based on the full texts of the papers, 18 items were qualified for the final analysis, which were selected in accordance with the scheme presented by Mazur and Orłowska [16]. The following inclusion criteria were used: 1. research on relationships between mental toughness and performance; 2 . availability of the full text of the article; 3. article in English.

\section{RESULTS}

Basic information on the research presented in the selected articles is shown in Table 1. 
Table 1. Papers included in the review

\begin{tabular}{|c|c|c|c|}
\hline Author(s) & Experimental group & Tools & Results \\
\hline Kuan, Roy [27] & $\begin{array}{l}\text { Wushu athletes, } \\
\text { participating in the } \\
\text { competitions, 19-27 } \\
\text { years old; } 40 \text { people; } \\
\text { Malaysia }\end{array}$ & $\begin{array}{l}\text { Psychological } \\
\text { Performance } \\
\text { Inventory } \\
\text { (PPI) }[5,17]\end{array}$ & $\begin{array}{l}\text { Wushu medallists were characterized by higher } \\
\text { mental toughness (self-confidence } M=21.82 \text {, } \\
\mathrm{SD}=2.72, \mathrm{p}=0.001 \text { ) and negative energy } \\
\text { control } \mathrm{M}=19.59, \mathrm{SD}=2.32 \text { ) compared to non- } \\
\text { medallists (self-confidence } \mathrm{M}=18.76, \mathrm{SD}=2.49 \text {; } \\
\text { negative energy control } \mathrm{M}=18.14, \mathrm{SD}=1.91 \text { ) } \\
\text { No differences in sports results were found } \\
\text { between players from different clusters } \\
\text { distinguished based on the strength of task } \\
\text { orientation and ego orientation }\left(\chi^{2}=0.98 \text {, }\right. \\
\mathrm{p}=0.612 \text { ). } \\
\text { The players included in different clusters } \\
\text { differed in terms of positive and negative } \\
\text { energy control. }\end{array}$ \\
\hline
\end{tabular}

Newland, University basketball Psychological

Newton, Finch - league players, 105

Harbke, Podlog women, 92 men,

[39]
Performance

Inventory -Alternative (PPI-A) [18]
There was no significant correlation between the total mental toughness index and the

basketball level of performance index $(r=0.12$ $\mathrm{p}=0.09$ ).

Men were characterized by greater mental toughness $(F(1,193)=10.55, p=0.001$

$\eta^{2}=0.05$ ).

Mental toughness was a predictor of the level of performance only in men $(F(3,88)=74.66$, $\mathrm{p}<0.001)$.

Drees, Mack Wrestlers, secondary school students, 54 boys, $14-18$ years old: the USA

The Mental Emotional and Bodily Toughness Inventory (MeBTough) [19]

Mental toughness positively correlated with age $(r=0.322, p<0.05)$ and the percentage of fights won $(r=0.272, p<0.05)$.

There was no significant correlation between mental toughness and training experience and years of training $(p>0.05)$.

There were significant differences in mental toughness between first- and fourth-grade students $(F(3,50)=2.86, p<0.05)$. Wrestlers who had a higher percentage of wrestling fights won in the season were characterized by greater mental toughness than other players.

Weissensteiner, Batsman in cricket, Mental Toughness at a high $(\mathrm{n}=11)$ and Abernethy $\begin{array}{ll}\text { Farrowd, Gross } & \text { lower }(n=10) \text { skill } \\ {[30]} & \text { level; } 20-38 \text { years, }\end{array}$ Australia

Players with greater batting skills were

characterized by higher mental toughness compared to players with lower technical skills $\left(F(1,19)=8.18, p<0.05, \eta^{2}=0.30\right)$. Significant intergroup differences were found in the following scales: personal achievements $\left(F(1,19)=6.17, p>0.05, \eta^{2}=0.24\right)$, perseverance $(F(1,19)=8.00, p>0.05$ $\left.\eta^{2}=0.30\right)$, self-efficacy $(F(1,19)=15.03, p>0.05$, $\left.\eta^{2}=0.44\right)$, task value $(F(1,19)=9.68, p>0.05$, $\left.\eta^{2}=0.34\right)$, goal commitment $(F(1,19)=7.40$, $p>0.05, \eta^{2}=0.28$ ).

Hagag, Ali [31] Fencers participating Psychological in the African Championships, 12 men and 10 women, Performance Inventory (PPI) $[5,17]$

African fencing championship medallists were characterized by greater mental toughness than those who did not win medals $(145.67 \pm 11.63$ vs $132.22 \pm 10.10)$. Significant differences were observed in self-confidence $(21.25 \pm 3.39$ vs $17.11 \pm 2.56)$, visualisation/ imagery control $(20.75 \pm 3.31$ vs $16.22 \pm 2.72)$ and positive energy control $(23.33 \pm 2.74$ vs $19.33 \pm 2.45$ ). Players with higher mental toughness were more often selected for team sports. 


\begin{tabular}{|c|c|c|c|}
\hline Rabab [37] & $\begin{array}{l}\text { University handball } \\
\text { team players; } 18 \text { men, } \\
\text { experimental group } \\
\text { ( } n=10) \text { participated in } \\
\text { a mental toughness } \\
\text { program ( } 3 \text { times a } \\
\text { week for } 8 \text { weeks), } \\
\text { Egypt }\end{array}$ & $\begin{array}{l}\text { Mental Toughness } \\
\text { Questionnaire } \\
\text { (MTQ48) [8] }\end{array}$ & $\begin{array}{l}\text { Positive correlations were found between } \\
\text { mental toughness and the effectiveness } \\
\text { of throws on the goal, with the strongest } \\
\text { correlations documented for total index } \\
\text { of mental toughness }(r=0.69, p<0.01) \\
\text { confidence in abilities }(r=0.59, p<0.01) \\
\text { interpersonal confidence }(r=0.64, p<0.01) \\
\text { and emotional control }(r=0.61, p<0.01) \text {. }\end{array}$ \\
\hline Cowden [36] & $\begin{array}{l}\text { Tennis players, } 25 \\
\text { boys and } 18 \text { girls } \\
\text { participating in the } \\
\text { tournament, aged } 11 \\
\text { to } 15 \text { years, } \\
\text { South Africa }\end{array}$ & $\begin{array}{l}\text { Sport Mental } \\
\text { Toughness } \\
\text { Questionnaire (SMTQ) } \\
{[9]}\end{array}$ & $\begin{array}{l}\text { Positive correlations were observed between } \\
\text { mental toughness and some indices of } \\
\text { performance level during the match (ranking } \\
r=-0.29, p<0.05 ; \text { match outcome } r=0.52 \text {; } \\
p<0.01 \text { ) and points scored at critical moments } \\
\text { of the game }(r=0.39, p<0.01 ; r=0.36, p<0.01 \text {; } \\
r=0.36, p<0.01) \text {. }\end{array}$ \\
\hline $\begin{array}{l}\text { Slimani, Miarka, } \\
\text { Briki, Cheour } \\
\text { [32] }\end{array}$ & $\begin{array}{l}32 \text { men, kickboxers } \\
\text { who won or lost in the } \\
\text { Tunisian championship }\end{array}$ & $\begin{array}{l}\text { Sports Mental } \\
\text { Toughness } \\
\text { Questionnaire (SMTQ) } \\
\text { [9] }\end{array}$ & $\begin{array}{l}\text { The winners in kickboxing fights were } \\
\text { characterized by higher mental toughness on } \\
\text { all scales }(p<0.001) \text {. } \\
\text { Mental toughness significantly correlated and } \\
\text { was a predictor of sports results in kickboxing } \\
(r=0.89 ; F(3,28)=34.235 ; p<0.001)\end{array}$ \\
\hline Petho [23] & $\begin{array}{l}236 \text { equestrian } \\
\text { athletes ( } 16 \text { men and } \\
220 \text { women), 18-78 } \\
\text { years old, } \\
\text { the United Kingdom }\end{array}$ & $\begin{array}{l}\text { Selected questions } \\
\text { of Mental Toughness } \\
\text { Questionnaire } \\
\text { (MTQ48) [8] }\end{array}$ & $\begin{array}{l}\text { There were no significant correlations between } \\
\text { the selected dimensions of mental toughness } \\
\text { and performance in equestrianism ( } p=0.928) \text {. }\end{array}$ \\
\hline $\begin{array}{l}\text { Beckford, } \\
\text { Poudevigne, } \\
\text { Irving, Golden } \\
\text { [33] }\end{array}$ & $\begin{array}{l}30 \text { sprinters, boys } \\
\text { participating in the } \\
\text { Jamaican secondary } \\
\text { school championships, } \\
\text { divided into equal } \\
\text { groups based } \\
\text { on previous } \\
\text { achievements }\end{array}$ & $\begin{array}{l}\text { Mental Toughness } \\
\text { Questionnaire } \\
\text { (MTQ48) [8] }\end{array}$ & $\begin{array}{l}\text { The elite sprinters were characterized by } \\
\text { greater mental toughness than their peers with } \\
\text { lower sporting achievements. }(t(28)=2.06 \text {, } \\
p=0.048) \text {. } \\
\text { The subscale of Challenge was significantly } \\
\text { different between the two groups of athletes } \\
(t(28)=2.55, p=0.017) \text {. } \\
\text { The level of mental skills was a predictor of } \\
\text { mental toughness }\left(R^{2}=0.38, F(4,25)=8.43 \text {, }\right. \\
p<0.01) \text {. }\end{array}$ \\
\hline $\begin{array}{l}\text { Beattie, Alqallaf, } \\
\text { Hardy [21] }\end{array}$ & $\begin{array}{l}89 \text { boys and } 107 \\
\text { adolescent girls } \\
\text { practising swimming } \\
\text { and their coaches, } \\
\text { the United Kingdom }\end{array}$ & $\begin{array}{l}\text { Swimming Mental } \\
\text { Toughness Inventory } \\
\text { (SMTI) [21] }\end{array}$ & $\begin{array}{l}\text { Players sensitive to punishment and insensitive } \\
\text { to rewards were characterized by greater } \\
\text { mental toughness and, consequently, they } \\
\text { swam faster. } \\
\text { Mental toughness did not depend on age }(\beta 1=- \\
0.06, p=0.32) \text { or gender }(\beta 2=0.08, p=0.63)\end{array}$ \\
\hline $\begin{array}{l}\text { Meggs, Chen, } \\
\text { Koehn [38] }\end{array}$ & $\begin{array}{l}48 \text { Ironman athletes } \\
\text { (including } 11 \text { women) } \\
\text { and } 66 \text { classic } \\
\text { triathletes (including } \\
23 \text { women), } \\
\text { the United Kingdom }\end{array}$ & $\begin{array}{l}\text { Mental Toughness } \\
\text { Questionnaire } \\
\text { (MTQ18) [8] }\end{array}$ & $\begin{array}{l}\text { Mental toughness positively correlated with } \\
\text { the subjectively assessed level of performance } \\
\text { and experiencing of a flow state, and was a } \\
\text { predictor of this state }(\mathrm{t}(112)=14.13, \mathrm{p}<0.001 \text {; } \\
\text { beta }=1.96) \text {. } \\
\text { The participants of the Ironman }(\mathrm{M}=66.53 \text {, } \\
\mathrm{SD}=6.56) \text { competition were characterized } \\
\text { by higher mental toughness }(\mathrm{t}(112)=8.43 \text {, } \\
\mathrm{p}<0.001) \text { compared to other triathletes } \\
(\mathrm{M}=58.10, \mathrm{SD}=7.26)\end{array}$ \\
\hline $\begin{array}{l}\text { Jones, Parker } \\
\text { [22] }\end{array}$ & 316 British triathletes & $\begin{array}{l}\text { Mental Toughness } \\
\text { Index (MTI) [22] }\end{array}$ & $\begin{array}{l}\text { The number of completed triathlon } \\
\text { competitions and mental toughness correlated } \\
\text { negatively with the best time ( } r=-0,439 \text { and } \\
r=-0.203 ; p<0.001) \text {. } \\
\text { With regards to the number of competitions } \\
\text { completed, mental toughness was the only } \\
\text { predictor of the best result (beta }=-0.189 \text {, } \\
p<0.001) \text {. }\end{array}$ \\
\hline $\begin{array}{l}\text { Fawver, Cowan } \\
\text { DeCouto, Lohse, } \\
\text { Podlog, Williams } \\
\text { [24] }\end{array}$ & $\begin{array}{l}169 \text { adolescent alpine } \\
\text { skiers } 15-18 \text { years old } \\
\text { (men } \mathrm{n}=81 \text {; women } \\
\mathrm{n}=88 \text { ) the USA }\end{array}$ & $\begin{array}{l}\text { Sport Mental } \\
\text { Toughness } \\
\text { Questionnaire (SMTQ) } \\
\text { [9] }\end{array}$ & $\begin{array}{l}\text { There was no relationship between mental } \\
\text { toughness and place in the ranking in technical } \\
\text { and speed competitions in alpine skiing } \\
\text { (p>0.05). }\end{array}$ \\
\hline $\begin{array}{l}\text { Kristjansdottir, } \\
\text { Johannsdottir, } \\
\text { Pic, Saavedra } \\
\text { [34] }\end{array}$ & $\begin{array}{l}142 \text { women soccer } \\
\text { players } 23-27 \text { years } \\
\text { old Iceland }\end{array}$ & $\begin{array}{l}\text { Sport Mental } \\
\text { Toughness } \\
\text { Questionnaire (SMTQ) } \\
\text { [9] }\end{array}$ & $\begin{array}{l}\text { The players of the national team in soccer had } \\
\text { significantly greater mental toughness } \\
(M=43.43) \text { than the players from the first } \\
(M=39.94) \text { and second }(M=35.15) \text { league } \\
(\mathrm{M}=18.993 ; p<0.001 ; \eta 2=0.226) \text {. } \\
\text { In particular, the players representing the } \\
\text { national team obtained a higher score in the } \\
\text { confidence subscale }(M=16.03) \text { than the } \\
\text { other players (first league } M=14.25 ; \text { second } \\
\text { league } M=12.29 ; F=15.947 ; p<0.001 ; \\
\left.\eta^{2}=0.192\right) \text {. }\end{array}$ \\
\hline
\end{tabular}




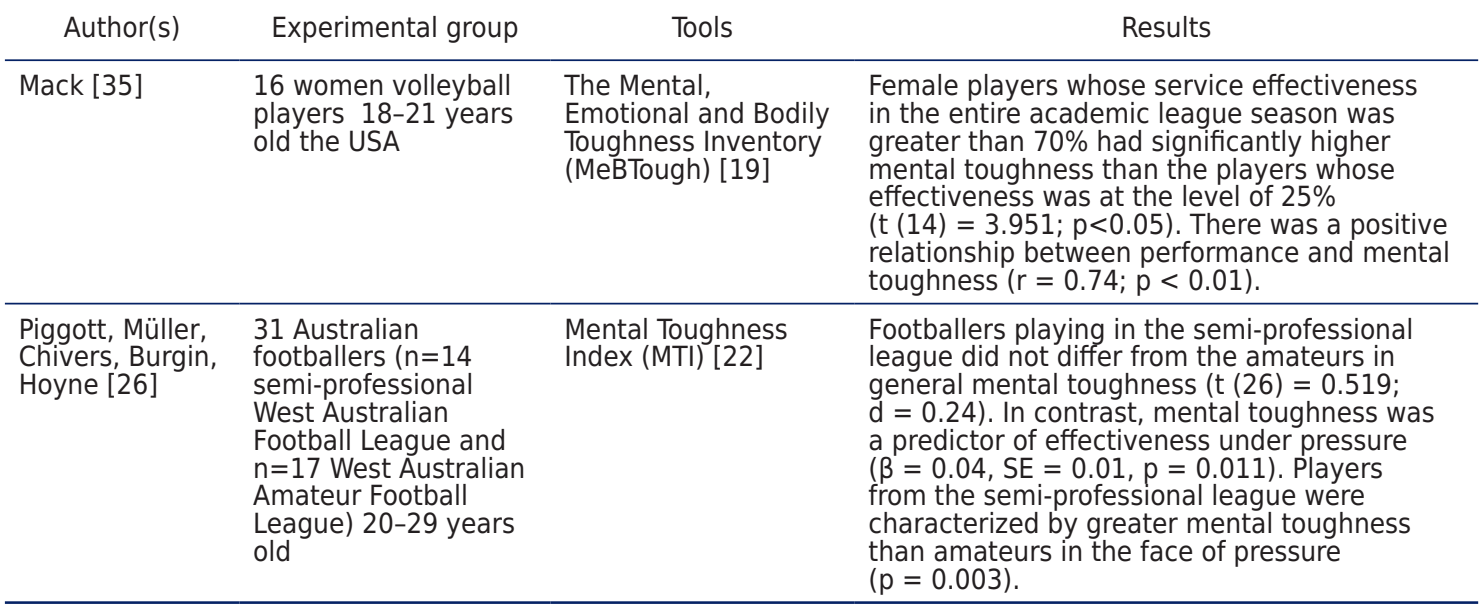

\section{TOOLS FOR ASSESSMENT OF MENTAL TOUGHNESS}

Various tools were used to measure mental toughness. They were listed and briefly discussed below.

Psychological Performance Inventory (PPI [5, 17]) contains 42 statements that make up 7 scales: self-confidence, negative thoughts control, positive thoughts control, attention control, visualization, performance imagery control, attitude. The reliability of the inventory measured by Cronbach's alpha ranges from 0.55 to 0.69 .

Performance Inventory-Alternative (PPI-A [18)) is an inventory consisting of 4 scales: determination, self-belief, visualization, positive cognition. It contains 14 statements. The reliability of the inventory measured by Cronbach's alpha is 0.81 .

The Mental, Emotional, and Bodily Toughness Inventory (MeBTough [19]) is a scale for diagnosis of psychological, physical and emotional element of mental toughness. It consists of 43 statements. The reliability of the inventory measured by Cronbach's alpha ranges from 0.93 to 0.95 .

Mental Toughness Questionnaire (MTQ48, MTQ18, MTQ [8]) consists of 4 main scales and 2 subscales: commitment, challenge, confidence: belief in one's own skills, self-confidence in interpersonal contacts, emotional control, life control. It contains 48 statements. The reliability of the questionnaire (Cronbach's alpha) is 0.90 .

Sports Mental Toughness Questionnaire (SMTQ [9]) contains 3 scales: control, stability, self-confidence. It consists of 14 statements. The Cronbach's alfa is 0.67 .

Mental Toughness Inventory (MTI [20]) contains 36 statements and takes into account 12 factors that make up mental toughness, such as task specific attention, task familiarity, stress minimisation, perseverance, positivity, positive comparison, self-efficacy, mental self-concept, goal commitment, personal best, potential, task value. The reliability of the inventory is high, with Cronbach's alpha ranging from 0.82 to 0.94 .

Swimming Mental Toughness Inventory (SMTI [21]) was developed based on MTI. It consists of 11 statements. The authors took into account factors critical to swimming. A coach assesses the extent to which his or her athlete shows certain behaviours that reflect mental toughness. The Cronbach's alfa is 0.91 .

Mental Toughness Index (MTI [22]) describes behaviour, emotions and thoughts of mentally tough athletes. It contains 8 statements, with index reliability falling within the range of Cronbach's alpha of 0.86-0.89. 


\section{EFFECT OF MENTAL TOUGHNESS ON SPORTING PERFORMANCE}

The vast majority of papers (16 of 18 studies included in the review) revealed a positive relationships between mental toughness and the sports results or performance level. Petho [23] did not establish correlations between the selected statements of the MTQ questionnaire and the results obtained in different equestrian events. However, it should be emphasized that the construct of mental toughness was not used in this survey. Answers to selected questions of the MTQ questionnaire were treated as indices of two variables: physical training and mental training. There were no significant correlations between these variables and the results obtained by beginners and intermediate-level riders in three equestrian events: dressage, show jumping and eventing. They also did not allow predicting the results obtained by the competitors. Surprisingly, the only negative predictor of sports results in equestrianism was motivation. Attention should be paid to at least two factors significantly different from the other studies included in the review. Firstly, the authors used only selected statements of the mental toughness scale in order to study the variables that were not entirely clearly defined: physical training and mental training. Secondly, in equestrian sports, results depend not only on the athlete (rider), but also on the horse and the relationship between each other. The latter seems to be only partially dependent on the athlete's mental toughness.

Also Fawver [24] did not confirm the relationship between mental toughness and performance in alpine skiing. It was expected that at the top of the national ranking of individual competitions would be players with high mental toughness and perfectionism. There were no differences in both psychological constructs between athletes occupying different places in the ranking. However, a negative relationship between mental resilience and time spent on competitions and indirect activities such as watching the rides of other competitors was revealed. The lack of expected dependencies may result from the athletes' young age $(\mathrm{M}=15.82)$.

According to Gucciardi [25], mental toughness changes over time, so perhaps it would be reasonable to conduct research in the senior alpine skiing team and to use ride time as an indicator of the level of performance.

Adult footballers playing in the semi-professional football league in Australia did not differ from amateurs in general mental toughness, but they were characterized by greater mental toughness in the face of pressure [26].

In other studies, relationships between mental toughness and sporting performance were reflected in: a) differences in the mental toughness of athletes with better and worse athletic performance; b) correlation coefficients between mental toughness and sporting performance; c) regression analysis results indicating mental toughness as a predictor of sports results/performance level.

The results of a cross-sectional study indicated higher mental toughness of medallists in Wushu competitions compared to non-medallists [27], Australian university rugby players who won the university rugby tournament compared to the British rugby teams who took the next place [28], teenage wrestlers with a higher number of fights won during the wrestling season compared to their peers who achieved worse results [29], athletes with a higher level of cricket batting skills compared to athletes with worse performance [30], African fencing championships medallists compared to non-medallists [31], kickboxing winners compared to losers [32], boys competing in sprinting at the elite level compared to their non-elite peers [33], female players of the Iceland national soccer team compared to players of the first and second league [34]. More mentally tough adolescents practising swimming achieved better results than their colleagues with lower mental toughness [21]. 
Mental toughness of volleyball players whose service efficiency during the season was over $70 \%$ was greater than that of less effective players [35]. Australian football players with greater sports skills revealed under pressure were characterized by greater mental toughness [26]. Many authors have found significant correlations between mental toughness and different indices of sports results/level of performance. Dress and Mack [29] have established positive relationships between mental toughness and the percentage of fights won in wrestling. Mental toughness correlated with some performance level indices during a tennis match and points scored at critical moments of the game [36]. Rabab [37] found a significant correlation between mental toughness of handball players and the effectiveness of throwing at the goal. Mental toughness in kickboxers correlated with the result obtained during competition [32]. Mental toughness indices were related to the subjectively assessed level of performance of triathletes and Ironman athletes [38] and the best time in triathlon competitions [22]. There was also a positive relationship between performance and mental toughness in adolescent women volleyball players [35].

Although Newland et al. [39] failed to find significant correlations between the total mental toughness index and basketball performance index, the researchers found that mental toughness was its predictor but only in men. Mental toughness also allowed predicting the results obtained by kickboxers [32]. In controlling the number of completed competitions, mental toughness was the only predictor of the best result of triathletes [22]. Mental toughness was a predictor of effectiveness under pressure in adult Australian footballers [26].

\section{SPORT AND MENTAL TOUGHNESS}

The relationship between mental toughness and sports results has been observed in various sports. These include individual sports, such as triathlon [22,38], swimming [21], track and field [33], wushu [27], kickboxing [32], tennis [36], wrestling [29], or fencing [31] and team sports: handball [37], rugby [28], cricket [30], soccer [34], Australian football [26], volleyball [35] and basketball [39]. A greater number of studies in individual sports may be due to the fact that the result depends on the performance of an individual, so that his or her mental properties may potentially be more closely related to the result. In the case of team sport, possible deficits of players can be compensated by other team members.

\section{RELATIONSHIPS BETWEEN AGE AND MENTAL TOUGHNESS}

The reviewed articles present the results of the study of athletes of various ages, starting from early adolescence [21, 24, 29, 33, 36], through youth [27, 28, 35, 37, 39], to adulthood [22, 25, 29, 34, 38]. The oldest studied competitor was 78 years old [23]. Most of the groups were homogeneous in terms of age. This may be the reason why relationships between age and mental toughness were relatively rarely sought, or the mental toughness was compared for athletes of different ages. Mental toughness positively correlated with the age of young wrestlers - secondary school students. There were significant differences in mental toughness between first- and fourth-grade students [29]. Mental toughness did not depend on the age of adolescent swimmers [21].

\section{GENDER DIFFERENCES IN MENTAL TOUGHNESS}

The study included both athletes of the same sex, with a similar number of men $(n=626)$ and women $(\mathrm{n}=741)$, as well as mixed groups (216 persons). Newland et al. [39] compared mental toughness of male and female university basketball players and found greater mental toughness in men. Only in men mental toughness allowed to predict the level of performance. In the research by Fewver et al. [24], boys practicing alpine skiing were characterized by greater psychological resistance, confidence and control than girls. Beatie et al. [21] did not find any differences in the mental toughness of girls and boys practising swimming. 


\section{DISCUSSION}

In the Polish literature to date, the issues of mental toughness have not been discussed very often. The present review allows for systematization of the knowledge and results of the latest research on mental toughness in sport.

The results of almost all studies included in the review confirm the positive relationship between mental toughness and sports results. Athletes with high mental toughness also experience anxiety, stress, and pressure of sport competition [4], but they cope better with such situations $[40,41]$, usually approaching them as a challenge. Elite track and field athletes considered all adversities and obstacles in this way, which differentiated them from the competitors at an average sports skill level [41]. Mentally tough people are characterized by optimistic attitudes and commitment during the competition [7, 42].

Research confirms that there is a link between mental toughness and sports performance. Mentally tough athletes perform both motor and cognitive tasks better and have better sport results. Being tough allows athletes to effectively use motor skills in stressful situations [43]. So far, no single mechanism responsible for the impact of mental toughness on performance has been identified [44]. Undoubtedly, one of the important elements is the athletes' perception of their own effort and fatigue. This interpretation can be important in understanding the relationship between mental toughness and pain, discomfort or difficulty [43]. Explaining this relationship, Crust [10] refers to Rejski's pain sensation model. He treats the perception of effort as an active process, related to learning through experience and the transfer of information to the cerebral cortex. Understanding the mechanisms underlying the relationship between mental resistance and sports performance requires both further research and theoretical analysis.

Older players were characterized by greater mental toughness than younger athletes. It can be stated that, with age, athletes acquire various psychological skills, are more emotionally mature, which may contribute to greater mental toughness [7, 29, 45]. It is interesting that in a study of wrestlers, sports experience did not differentiate mental toughness. The insignificance of this correlation could have been determined by the adopted division of players due to their sports experience. Four groups were distinguished: wrestlers in the first year of training, those who trained 2-5 years, 6-10 years, and over 10 years. Competitors included in the second group (up to 5 years) should be in a group with little experience (group one). Three groups should be created, with small, medium and large experience [29]. However, the results of Grgurinović and Sindik [46] showed no differences in mental toughness in Croatian athletes depending on their age and experience. These issues need further research involving athletes of different ages and experience.

It is important to emphasise the role of the coach in building mental toughness and creating the right environment for the acquisition of different mental skills. In particular, cooperation with women requires more attention from the coach in building self-confidence [39]. It represents an important element of mental toughness. Gucciardi [2] emphasized the importance of the coach in the development of athletes' mental toughness by building proper relationships between coaches and athletes, work philosophy, appropriate training environment and specific strategies (e.g. learning to react to a mistake).

In his analyses, Cowden [36] confirmed a correlation between winning a tennis match and high mental toughness, but also stressed the importance of other factors affecting sporting success, such as technical, tactical and motor skills, which can differentiate between winning and losing players in their tennis matches. These components should be taken into account in further research. 
Various research tools were used to measure mental toughness in the studies included in the present review. Consequently, this makes it difficult to compare the obtained results. The variety of scales and inventories used results from different definitions of mental toughness. Researchers refer to many psychological concepts and models in order to define this construct as accurately as possible [47].

\section{Objectives for further Research}

The comparison of the results of studies covered by the review allows for identification of the following objectives for future research:

- looking for correlations between stress management strategies in sport competition situations and mental toughness;

- analysing mental toughness and other psychological skills affecting sporting performance of athletes and their competitors, taking into account physical, technical, tactical and psychological factors;

- conducting longitudinal studies on mental toughness in order to establish correlations between mental toughness and the age and sporting experience of athletes in different sports;

- determining the importance of the coach's role in creating an environment conducive to the development of mental toughness;

- explaining the correlations between mental toughness and a flow state in individual and team sports;

- searching for differences in mental toughness of women and men;

- evaluating correlations of physiological factors and other psychological components with mental toughness;

- explaining the mechanisms of the impact of mental toughness on performance levels.

\section{CONCLUSIONS AND LIMITATION}

The following conclusions were formulated based on the review of studies:

1. Studies have confirmed the positive correlations between mental toughness and sports results and performance level.

2. The large variety of applied tools (PPI, PPI-A, SMTQ, MTQ48, MTI, SMTI, MeBTough) may partially explain the differences in the established correlations.

3. Further analysis is needed to examine sexual differentiation, differences between individual and team sports, the correlations of mental toughness with training experience and the age of players, and effective methods to improve mental toughness.

The following limitations also need to be acknowledged:

1. The studies differently defined mental toughness, and different research tools were used, which makes comparing results difficult.

2. n most cases, the study groups were small, which limits the possibilities for results generalization.

\section{REFERENCES}

[1] Holt N.L, Dunn J.G.H. Toward a grounded theory of the psychological competencies and environmental conditions associated with soccer success. J Appl Sport Psychol. 2004;16:199-219. https://doi.org/10.1080/10413200490437949

[2] Gucciardi DF, Gordon S, Dimmock J, Mallet C. Understanding the coach's role in the development of mental toughness: Perspectives of elite Australian football coaches. J Sport Sci. 2009;27(13):1483-1496. https://doi. org/10.1080/02640410903150475

[3] Hardy L, Bell J, Beattie S. A neuropsychological model of mentally tough behavior. J Personal. 2013;82(1):69-81. https://doi.org/10.1111/jopy.12034

[4] Jones G, Hanton S., Connaughton D. A framework of mental toughness in the world's best performers. Sport Psycholog. 2007;21(2):243-264. https://doi.org/10.1123/tsp.21.2.243 
[5] Loehr J.E. Mental toughness training for sports: achieving athletic excellence. Lexington: Stephen Greene Press; 1986.

[6] Jones G, Hanton S, Connaughton D. What is this thing called mental toughness? An investigation of elite sport performers. J Appl Sport Psychol. 2002;14:205-218. https://doi.org/10.1080/10413200290103509

[7] Gucciardi DF, Gordon S, Dimmock J. Advancing mental toughness research and theory using personal construct psychology. Int Rev Sport Exerc Psychol. 2009;2:54-72. https://doi.org/10.1080/17509840802705938

[8] Clough P, Earle K, Sewell D. Mental toughness: the concept and its measurement. In: Cockerill I, editor. Solutions in sport psychology. London: Thomson; 2002, 32-45.

[9] Sheard M. Mental toughness. The mindset behind sporting achievement. London, New York: Routledge; 2013. https:// doi.org/10.4324/9780203103548

[10] Crust L, Clough P. Developing mental toughness: From research to practice. J Sport Psychol Action. 2011;2:21-32 https://doi.org/10.1080/21520704.2011.563436

[11] Crust L, Azadi K. Mental toughness and athletes' use of psychological strategies. Eur J Sport Sci. 2010;10(1):43-51. https://doi.org/10.1080/17461390903049972

[12] Jemmy S, Easvaradoss, Mental toughness and positivity as predictors of performance strategies used among competing athletes. Int J Sport Sci Fitness. 2018;8(2):98-119.

[13] Ajilchi B, Amini HR, Ardakani ZP, Zadeh MM, Kisely S. Applying mindfulness training to enhance the mental toughness and emotional intelligence of amateur basketball players. Australasia Psychiatr. 2019;27(3):291-296. https://doi. org/10.1177/1039856219828119

[14] Connaughton D, Jones G, Hanton S. The development and maintenance of mental toughness in the world's best performers. Sport Psycholog. 2010;24;168-193. https://doi.org/10.1123/tsp.24.2.168

[15] Gould R, Diffenbach K, Moffet A. Psychological talent and its development in Olympic Champions. J Appl Sport Psychol. 2002;14:177-210. https://doi.org/10.1080/10413200290103482

[16] Mazur Z, Orłowska A. Jak zaplanować i przeprowadzić systematyczny przegląd literatury [How to plan and conduct a systematic review of literature]. Polskie Forum Psychologiczne. 2018;23(2):235-251. Polish.

[17] Golby J, Sheard M, Wersch A. Evaluating the factor structure of the Psychological Performance Inventory. Percept Motor Skill. 2007;105:309-325. https://doi.org/10.2466/pms.105.1.309-325

[18] Gucciardi D. Measuring mental toughness in sport: A psychometric examination of the Psychological Performance Inventory-A and its Predecessor. J Personal Assess. 2012;(94)4:393-403. https://doi.org/10.1080/00223891.2012. 660292

[19] Mack M, Ragan B. Development of the Mental, Emotional, and Bodily Toughness Inventory in collegiate athletes and nonathletes. J Athlet Train. 2008; 43(2):125-132. https://doi.org/10.4085/1062-6050-43.2.125

[20] Middleton S, Marsh H, Martin J, Richards G, Perry C. Developing a test for mental toughness: The Mental Toughness Inventory (MTI). Conference publication; 2005.

[21] Beattie S, Alqallaf A, Hardy L. The effects of punishment and reward sensitivities on mental toughness and performance in swimming. Int J Sport Psychol. 2017; 48(3):1-9.

[22] Jones G, Parker J. An analysis of the size and direction of the association between mental toughness and Olympic distance personal best triathlon times. J Sport Health Sci. 2017;8(1):1-6. https://doi.org/10.1016/j.jshs.2017.05.005

[23] Petho D. The performance success within the competitive equestrian field: A novice and intermediate rider focused investigation. J Sport Exerc. 2017;12(3):857-871. https://doi.org/10.14198/jhse.2017.12.Proc3.10

[24] Fawver B, Cowan RL, DeCouto B, Lohsep KR, Podlog L, Williams AM. Psychological characteristics, sport engagement, and performance in alpine skiers, Psychol Sport Exerc. 2019;47:101616. https://doi.org/10.1016/j. psychsport.2019.101616

[25] Gucciardi DF, Hanton S, Gordon S, Mallett C J, Temby P. The concept of mental toughness: Tests of dimensionality, nomological network, and traitness. J Personal. 2014; 3(1):26-44. https://doi.org/10.1111/jopy.12079

[26] Piggott B, Müller S, Chivers P, Burgin M, Hoyne G. Coach rating combined with small-sided games provides further insight into mental toughness in sport. Front Psychol. 2019: 10:1552. https://doi.org/10.3389/fpsyg.2019.01552

[27] Kuan G, Roy J. Goal profiles, mental toughness and its influence on performance outcomes among Wushu athletes. J Sport Sci Med. 2007;6:28-633.

[28] Sheard M. A cross-national analysis of mental toughness and hardiness in elite university rugby league teams. Percept Motor Skill. 2009;109:213-223. https://doi.org/10.2466/pms.109.1.213-223

[29] Drees M, Mack M. An examination of mental toughness over the course of a competitive season. J Sport Behavior. 2012;35(4):377-386.

[30] Weissensteiner J, Abernethy B, Farrowd D, Gross J. Distinguishing psychological characteristics of expert cricket batsmen. J Sci Med Sport. 2012;15:74-79. https://doi.org/10.1016/j.jsams.2011.07.003

[31] Hagag H, Ali M. The relationship between mental toughness and results of the Egyptian fencing team at the 9th AllAfrica Games. Move Health. 2014;14:85-90.

[32] Slimani M, Miarka B, Briki W, Cheour F. Comparison of mental toughness and power test performances in high-level kickboxers by competitive success. Asian J Sport Med. 2016;7(2):1-7. https://doi.org/10.5812/asjsm.30840

[33] Beckford T, Poudevigne M, Irving R, Golden K. Mental toughness and coping skills in male sprinters. J Human Exerc. 2016;11(3):338-347. https://doi.org/10.14198/jhse.2016.113.01

[34] Kristjansdottir H, Johannsdottir KR, Pic M, Saavedra JM. Psychological characteristics in women football players: Skills, mental toughness, and anxiety. Scand J Psychol. 2019; 60(6):609-615. https://doi.org/10.1111/sjop.12571

[35] Mack M. An Examination of the relationship between mental toughness, psychological skills, coaches' ratings, and athletic performance. J Sport Behavior. 2019;(42)2:142-157.

[36] Cowden R. Competitive performance correlates of mental toughness in tennis: A preliminary analysis. Percept Motor Skill. 2016;123(1): 341-360. https://doi.org/10.1177/0031512516659902

[37] Rabab M. The effects of mental toughness training on athletic coping skills and shooting effectiveness for nationa handball players. Sci Move Health. 2015;15(2):431-435. 
[38] Meggs J, Chen M, Koehn S. Relationships between flow, mental toughness and subjective performance perception in various triathletes. Percept Motor Skill. 2018;1-12. https://doi.org/10.1177/0031512518803203

[39] Newland A, NewtonM, Finch L, Harbke C, Podlog L. Moderating variables in the relationship between mental toughness and performance in basketball. J Sport Health Sci. 2013;2:184-192. https://doi.org/10.1016/j.jshs.2012.09.002

[40] Kaiseler M, Polman R, Nicholls A. Mental toughness, stress, stress appraisal, coping and coping effectiveness in sport. Personal Ind Diff. 2009;47:728-733. https://doi.org/10.1016/j.paid.2009.06.012

[41] Nicholls A, Levy A, Polman R, Crust L. Mental toughness, coping self-efficacy, and coping effectiveness among athletes. Int J Sport Psychol. 2011;42:513-524.

[42] Nicholls, A, Polman, R, Levy A, Backhouse S. Mental toughness, optimism, pessimism, and coping among athletes. Personal Ind Diff. 2008;44:1182-1192. https://doi.org/10.1016/j.paid.2007.11.011

[43] Crust L, Clough P.J, Relationship between mental toughness and physical endurance. Percept Motor Skill. 2005;100(1):192-194. https://doi.org/10.2466/pms.100.1.192-194

[44] Clough P.J, Earle K. When the going gets tough: A study of the impact of mental toughness on perceived demands. J Sport Sci. 2002;20(1);61.

[45] Nicholls A, Polman R, Levy A, Backhouse S. Mental toughness in sport: Achievement level, gender, age, experience, and sport type differences. Personal Ind Diff. 2009;47(1):73-75. https://doi.org/10.1016/j.paid.2009.02.006

[46] Grgurinović T, Sindik J. Application of the mental toughness/ hardness scale on sample of athletes engaged in different types of sports. Phys Cult. 2015;69(2):77-87. https://doi.org/10.5937/fizkul1502077G

[47] Gucciardi D, Hanton S, Fleming S. Are mental toughness and mental health contradictory concepts in elite sport? A narrative review of theory and evidence. J Sci Med Sport. 2017;20:307-311. https://doi.org/10.1016/j. jsams.2016.08.006 